\title{
Influence of UNESCO in the Development of Lifelong Learning
}

\author{
Jarin Akther \\ Lecturer, Institute of Education and Research, University of Chittagong, Chittagong, Bangladesh \\ Email: jarin.ier@cu.ac.bd
}

How to cite this paper: Akther, J. (2020). Influence of UNESCO in the Development of Lifelong Learning. Open Journal of Social Sciences, 8, 103-112.

https://doi.org/10.4236/jss.2020.83010

Received: February 4, 2020

Accepted: March 7, 2020

Published: March 10, 2020

Copyright () 2020 by author(s) and Scientific Research Publishing Inc. This work is licensed under the Creative Commons Attribution International License (CC BY 4.0).

http://creativecommons.org/licenses/by/4.0/

\begin{abstract}
The concept of lifelong learning has been retrieved from a gradual transition of lifelong education. UNESCO as an international organisation has a significant role and contribution in promoting lifelong learning around the world. This study is aiming to look over the historical change of the concept of "lifelong education" to "lifelong learning", and UNESCO's influence and position on the changes within the context of developed and developing countries. This is historical research, which will describe the historical moments regarding lifelong learning and UNESCO's contribution. The study has found that the new form of global economy (neo-liberalism and capitalist approach) has created the need for individual's employment, which has influenced the transitional change of the lifelong learning concept. It has also found that UNESCO's influence and contribution are much more significant in developing or lowincome countries while it has less of an impact on developed countries.
\end{abstract}

\section{Keywords}

Lifelong Education, Lifelong Learning, UNESCO, Developed Countries and Developing Countries

"Life is limited, while learning is limitless."

\section{Introduction}

Lifelong learning comprises all the phases of learning from pre-school to postretirement including all spectrums of learning (Laal, 2011). Different countries have different policies for promoting lifelong learning. Industrialised and developed countries support lifelong learning by providing the opportunity to de- 
velop new skills and training for upgrading professional status with new technology. On the other hand, for developing countries, basic literacy and learning needs are the important elements for continuing further learning. As a result, they focus on basic literacy and adult literacy for ensuring lifelong learning.

Lifelong learning has a historical background of continual change under the two terms "adult education" and "lifelong education". These changes occurred in order to influence social, political, economic, and theoretical changes around the world (Milana, 2012; Medel-Añonuevo et al., 2001). Different international entities such as UNESCO, organisation for economic co-operation and development (OECD) and World Bank have been working on the changes to promote and implement lifelong learning policies in their member states (Milana, 2012). UNESCO has been working for lifelong learning for more than five decades. The organisation created an immense influence across the globe for the development of lifelong learning by publishing two worldwide recognised reports: Faure Report and Delors report (Schuetze, 2006). Moreover, the International Conference on Adult Education is another initiative of UNESCO which endorses lifelong learning for adults (Medel-Añonuevo, Ohsako, \& Mauch, 2001).

This paper has presented the investigation on the history of emerging concept of "lifelong learning". UNESCO is one of the world recognised and highly reputed international organisations and it has a great influence on promoting lifelong learning. Therefore, this paper is aiming to portray the influence of UNESCO on the conceptual and tangible transformation of "lifelong learning". This paper has also presented the data from different studies and opinion of different researchers with critical analysis. This paper would illustrate the contribution and influence of UNESCO, which is a distinctive study in the field of this particular research area.

\section{The Purpose of the Study}

UNESCO is one of the pioneering institutions that introduced lifelong learning globally. The purpose of the study is to illustrate the historical change of the concept of "lifelong education" to "lifelong learning", and UNESCO's influence and position on the changes within the context of developed and developing countries across the globe.

\section{Methodology}

It is a historical investigation, which will show the influence and contribution of UNESCO to promote lifelong learning in both developed and developing countries. This type of research presents the historical moments, nevertheless they permit a "performance" of developing ideas (Denzin \& Lincoln, 2005). The resources for historical investigation could be grouped into four categories: documents, numerical records, oral statements and record, and relics (Fraenkel, Wallen, \& Hyun, 2011). Here in this study, all the information was collected from reviewing documents like journal articles, books and UNESCO publica- 
tions. If any researcher uses data collected earlier by other researchers or other purpose than research, such as official statistics, administrative records, or other accounts kept routinely by organization, this type of source would be called as secondary data sources (Hox \& Boeije, 2005). Therefore, the documents which were used for this research purpose could be defined as secondary data sources. Before analysing data, researchers evaluate data by external and internal criticism. External criticism refers to the genuineness of the documents and internal criticism denotes the content accuracy of the documents (Fraenkel, Wallen, \& Hyun, 2011).

\section{The historical changes of lifelong learning concept and UNESCO}

At the end of the 1960s, the lifelong education movement reached a turning point in a new political, social, and economic reality with the collective entity and state responsibility of the adult education paradigm (Barros, 2012). There is an argument that the concept of lifelong learning was derived from adult education (Milana, 2012: p. 104). Milana (2012) argued 4 trends influenced the change of language from "education" to "learning". These are behind the change: 1) the change of traditional approaches of teacher-learner interaction; 2) the impact of postmodernist theory which described liberal and emancipated learning; 3) The influence of personal interest on individual learning activities; and 4) The impact of privatization of adult education (not a public good), which reduced the state responsibility, where learners are now a consumer and learning is a commodity. UNESCO introduced lifelong education as a new concept at $2^{\text {nd }}$ International Conference on Adult Education (CONFINTEA II) in 1970 (Elfert, 2015).

In 1972, UNESCO published the Faure report: Learning to Be which was a milestone for the field of lifelong education. Lifelong education means the right of citizens with a collective entity (Barros, 2012: p. 120). Barros (2012) argued in the $21^{\text {st }}$ century that the concept of lifelong learning should be replaced with lifelong education in neoliberal globalisation policy. Because of the open market economy, lifelong learning stands behind the individual duty (Barros, 2012: p. 120) to gain knowledge and skill for earning money from the labour market (Milana, 2012). The promotion of lifelong learning is mainly linked with OECD and European Union (EU) (Barros, 2012). In the Delors report, UNESCO also started to use the term "lifelong learning" instead of "lifelong education" because of the influence of OECD and World Bank. The UNESCO Institute for Education (UIE) was established in 1951 and was the core point for educationist around the world to conduct research and studies about the principals of educational policies (Milana, 2012: p. 108). After the shifting of the terminology to "lifelong learning", UIE was renamed by UNESCO to the Institute for Lifelong Learning (UIL).

UNESCO's influence on lifelong education development in the 1970s

One of the important reports of UNESCO was Learning to be: The World of Education Today and Tomorrow presented in 1972 at the "International Commission on the Development of Education", chaired by Edger Faure who was the 
former French minister. This Faure report defined lifelong education as the right of an individual's political, economic, and cultural progress (Medel-Añonuevo, Ohsako, \& Mauch, 2001). It also emphasised the solidarity and cooperation between developed and developing countries. After the report, UIE published nine monographs, conducted several projects and organised seminars to explore the conceptual foundation and theoretical framework for lifelong education, and the operational aspects of a system of lifelong education (Elfert, 2013). Elfert (2013) further described that these research and projects defined lifelong education beyond fundamental and basic education, which is available for any age group at any level. Elfert (2015) argued Faure report was not successful for developing countries, as lifelong education was a luxury concept.

UNESCO's influence on lifelong learning in the 1980s

Twenty-four years later, in 1996, UNESCO released another report Learning. The Treasure Within where "lifelong education" was replaced with the term of "lifelong learning" for its holistic approach to learning in every domain of individual life. It is otherwise known as the Delors report and was published in a time after the cold war when demand for employment was high during a neo-liberal and capitalist global crisis economy (Delors, 1998). The report mainly highlighted the employment and job market opportunities of the contemporary social needs. The OECD and World Bank made huge impacts on the Delors report (Elfert, 2015). Elfert also argued that the OECD's conception of the knowledge economy and human capital theory influenced UNESCO to think about learning society within economic lens.

Delors report also described the tension between universal and individual; traditional and modernity; and spiritual and material. It focused on individual skill development, employment, and economy, rather than spiritual and traditional values. Medel-Añonuevo et al. (2001) stated that the definition of lifelong learning, according to Delors report, is retaining and learning new skills to be adopted in a rapidly changing work place. The authors criticised that the meaning of "lifelong learning" in the Delors report was hidden under the term "Lifelong (L)earning". Many countries measured lifelong learning as the outcome of economic profit rather than humanistic outcomes (Morgan-Klein \& Osborne, 2007).

Medel-Añonuevo et al. (2001) also asserted the term "lifelong learning" emphasised the individual interest. These authors further identified that the individual learning agency replaced the state role and responsibility for lifelong learning. This report made a significant impact on many countries for lifelong learning. Delors report took initiatives for 50 countries with developing lifelong learning indicators, reflection for educational reform and pilot projects (Elfert, 2015). Delors report portrayed lifelong learning as a way to create a future global society where solidarity, equality and responsibility would be maintained as a Utopian aim. However, the report draws less impact on the development of lifelong learning in developing countries. Developing countries are suffering from many 
problems such as poverty, illiteracy, health care, and basic primary education. Lifelong learning could be operated in three different levels: micro level (family), meso level (school, community, and workplace) and macro level (societal, national, and global) (Medel-Añonuevo, Ohsako, \& Mauch, 2001), which could not be appreciated for the developing countries because of financial constraints (Burnett, 2008). Many other issues of Delors report like the four pillars of learning, the role of teachers, globalisation, learner as a self-actualizing agent, and equality, were valued and critically analysed across the world. Elfert (2015) argued Delor's report's four pillars of learning became a catch phrase are still being frequently cited in policy reports. The author also stated this report had an influence on the European Commission report Memorandum on Lifelong Learning of 2000.

Another concept of globalisation refers to the open market economy, which was sometimes a threat for accessing developing countries because of global economic competition. Many researchers and practitioners criticised lifelong learning, because it's too ambitious for developing countries and only focuses on rich countries (UNESCO, 2002). In Delors report, the contemporary debates like neo-liberal agenda, public good, privatisation and cross-national testing were paid attention to a rich country (Mundy, 1999: p. 42). Schuetze (2006) claimed that the report failed to address some problems raised in third world countries, e.g. globalisation, unequal social, political, and economic systems.

UNESCO for adult education and lifelong learning in the 1990 s and $21^{\text {st }}$ Century

In 1997, UNESCO organised the Fifth International Conference on Adult Education (Confintea, 1997), where adult literacy, adult basic learning, vocational and technical learning for further learning were discussed within the lifelong learning perspective. The conference emphasis was on "adult learning" instead of "adult education" because of the influence of the Delors report (Elfert, 2013). The continuation of the conference, CONFINTEA VI was held in Brazil in 2009. The report from the conference depicted the importance of adult learning within sustainable economic and human development concepts (Confintea VI, 2009). This report also stated that adults like to lead their lives by upgrading their personal and work life through skill development (Laal, 2011). Furthermore, adults are more interested in the subjects which are related to their lives. Sutherland \& Crowther (2008) stated that "adults are not very inclined...in which they cannot see the meaning and importance". CONFINTEA V and CONFENTIA VI had little reflection on adult psychology. The conferences had little impacts on low income countries that rely on external funding (Wagner, 2011).

\section{UNESCO for promoting higher education provisions}

The higher education (setting) is an opportunity that helps to develop and implement lifelong education setting to support lifelong learning (Knapper \& Cropley, 2000). UNESCO organized the World Conference on Higher Education 
(WCHE) for promoting higher education as a part of lifelong learning in 1998 and 2009. The targets of the conferences were to ensure quality, equality, partnership, and cooperation of higher education within member countries (UNESCO, 1998; UNESCO, 2009). UNESCO organised the conferences at a time when the number of private universities was increasing, and the government budget for higher education was decreasing (Uvalić-Trumbić, 2010). The conferences also mentioned the quality and mechanisms of higher institutions both for public and private institutions and gave priority to employment and job skills for the global market economy.

Lifelong learning is a learning opportunity available for all age groups. The conferences drew no awareness for the access, and provisions of untraditional learners or mature-age students (Knapper \& Cropley, 2000: p. 4) in higher education. Though lifelong learning promotes the provision for all learners beyond their age limit, in this conference no policy or facility has been derived to admit lifelong learners in universities' undergraduate courses. Therefore, many universities have not yet provided equal opportunity for the mature-age learners as traditional learners.

\section{UNESCO Recent Activities}

It is important to recognise that lifelong learning has sustainable development as a core point. Laal (2011) stated Walters S. claims, our planet won't survive, if it is not a learning planet, and sustainable development will be achieved by learning through life. UNESCO is also giving emphasis to future upcoming issues on education and learning with a sustainable development concept. In 2015, UNESCO published the document Rethinking Education, inspired by the Faure report and Delors report, which focused on the challenges and demand of education for the $21^{\text {st }}$ century. The report showed that education is a right and is considered as a public good (UNESCO, 2015). Here, education and learning are defined both in economic and humanistic approaches. Educational policies are recognised taking sustainable development goals (SDGs) as the central point. The report shows that world population doubled from 1950 to 2013 and poverty declined by half between 1990 and 2000 (UNESCO, 2015).

After adaptation of SDGs in $70^{\text {th }}$ session of United Nation General Assembly, UNESCO has taken particular importance on global literacy and has taken steps to implement 2030 SDGs within the lifelong learning framework (UIL, Annual Report, 2016; UIL, Annual Report, 2018). Very recently UNESCO has been focusing on adult learning and education for promoting lifelong learning (UIL, Annual Report, 2019). Hence, the concept of lifelong learning has been modifying with global learning needs and realities.

\section{UNESCO's initiatives for Developing Countries}

Both the Faure and the Delors reports were criticised by many scholars for the Utopian viewpoints which were only possible in developed countries (Elfert, 2015). UNESCO was also working for developing countries' educational policies context. In 1979, UIE started to work on literacy for developing countries, in the 
form of case studies, policy-oriented seminars and researches among developing countries around the world (Elfert, 2013). UIE also focused on functional literacy within industrialised countries. In the 1990s, UIE published ALPHA series, which reflected on literacy research and basic education for industrialised countries.

In 1990, the Education for All (EFA) conference was held at Jomtien in Thailand, and was organised by the United Nations (UN) with cooperation from UNESCO, United Nations Children's Fund (UNICEF), the World Bank and several other UN organisations (Elfert, 2013). The conference focused on education as a right to ensure the basic learning needs and primary education for children, youth, and adults. One decade later, another EFA conference was held in Dakar, where the global leaders agreed on Millennium Development Goals (MDGs) (UNESCO, 2000). Carm (2013) stated both of the EFA conferences had more emphasis on universal primary education with formal schooling than on adult learning or lifelong learning. For this reason, EFA policies were much more welcomed by the developing countries than the developed countries.

\section{UNESCO in developed countries}

OECD has been working for the development of lifelong learning across developed countries for the last two decades (OECD, 2007). OECD defined lifelong learning as the benefits of the labour market and knowledge economy (Elfert, 2015). However, UNESCO mainly focused on basic learning needs, giving priority to the demands of low-income countries. Developed countries tend to follow OECD's lifelong learning policies, which reinforced their contemporary needs. OECD's vision of lifelong learning has been spreading to other global and regional agencies, mainly the EU and the World Bank (Milana, 2012: p. 109). OECD develops educational policies for rich countries, while UNESCO works for the low-income countries. Burnett (2011) argued that because of OECD, UNESCO decreased the educational influence on "northern" countries of the world than "southern" ones. Therefore it could be said that UNESCO has limited influence on developed countries to promote lifelong learning.

\section{Conclusion}

Over time, the meaning of lifelong learning has been modified with the political, social, and economic changes around the world. Lifelong learning is now more described in the economic view with neoliberalism, democratic, and privatised societies. The replacement of "lifelong education" in Faure (1972) report with "lifelong learning" in Delors (1998) indicates the opportunity for individual learning interest. Adults are much more interested in this individual focus of learning which will benefit their respective lives, especially in the economic sector. This means the employee, workplace and financial interest are the top priority for lifelong learning. Additionally, the impact of OECD and World Bank in Delors report emphasized the "economic side" rather than the "humanistic side". Both the reports of UNESCO demonstrated lifelong learning in a highly 
improved society which was called "Utopia". So, the policies of the reports lose the appeal for developing countries. These countries, where the literacy or basic education is the crucial issue, EFA conferences, CONFINTEA V \& VI and WCHE developed a rigorous acceptance for basic learning needs and literacy. CONFINTEA $\mathrm{V}$ addressed the importance of adult literacy, vocational training, and new skills for lifelong learning. UNESCO World Conferences on Higher Education considered the higher education provision equal for all as a part of lifelong learning. The conferences did not build any policies on the provision and inclusion of matured learners. Overall, UNESCO is now giving more priority to the improvement of lifelong learning in developing countries. UNESCO received funding from several developed and northern countries for promoting lifelong learning in low-income countries. The organisation is now failing to make an impact on lifelong learning policies for developed countries.

\section{Limitation}

The main limitation of this study was all of the data that were collected from secondary data sources. (Johnston, 2017) argued that for secondary data analysis, researcher doesn't participate in data collection process and does not know exactly how it happened. Therefore, data could be manipulated. However, to conduct this study, researcher tried to avoid the most limitations of secondary data analysis by reflective examination and critical evaluation (Johnston, 2017). It would be better if further research could be done by collecting primary data. In this case, interviews from UNESCO officials and other contemporary scholars of this field would be appreciated for data accuracy and authenticity.

\section{Conflicts of Interest}

The author declares no conflicts of interest regarding the publication of this paper.

\section{References}

Barros, R. (2012). From Lifelong Education to Lifelong Learning. Discussion of Some Effects of Today's Neoliberal Policies. European Journal for Research on the Education and Learning of Adults, 3, 119-134. https://doi.org/10.3384/rela.2000-7426.rela0071

Burnett, N. (2008). The Delors Report: A Guide towards Education for All. European Journal of Education, 43, 181-187. https://doi.org/10.1111/j.1465-3435.2008.00347.x

Burnett, N. (2011). UNESCO Education: Political or Technical? Reflections on Recent Personal Experience. International Journal of Educational Research, 31, 315-318. http://www.elsevier.com/locate/ijedudev https://doi.org/10.1016/j.ijedudev.2010.11.014

Carm, E. (2013). Rethinking Education for All. Sustainability, 5, 3447-3472. https://doi.org/10.3390/su5083447

Confintea, V (1997). Adult Education the Hamburg Declaration the Agenda for the Future. In The Fifth International Conference on Adult Education Final Report (pp. 19-100). Hamburg: UNESCO. 
Confintea, VI (2009). Final Report. In The Sixth International Conference on Adult Education (pp. 6-121). Belem: UNESCO.

Delors, J. (1998). Learning. The Treasure within. Paris: UNESCO.

Denzin, N., \& Lincoln, Y. (2005). Introduction: The Discipline and Practice of Qualitative Research. In N. Denzin, \& Y. Lincoln (Eds.), The Sage Handbook of Qualitative Research (pp. 1-32). Thousand Oaks, CA: Sage Publications Ltd.

Elfert, M. (2015). UNESCO, the Faure Report, the Delors Report, and the Political Utopia of Lifelong Learning. European Journal of Education, 50, 88-100. https://doi.org/10.1111/ejed.12104

Elfert, M. (2013). Six Decades of Educational Multilateralism in a Globalising World: The History of the UNESCO Institute in Hamburg. International Review of Education, 59, 263-287. https://doi.org/10.1007/s11159-013-9361-5

Faure, E. (1972). Learning to Be: The World of Education Today and Tomorrow. Paris: UNESCO.

Fraenkel, J. R., Wallen, N. E., \& Hyun, H. H. (2011). How to Design and Evaluate Research in Education. New York: McGraw-Hill Humanities/Social Sciences/Languages.

Hox, J. J., \& Boeije, H. R. (2005). Data Collection, Primary vs. Secondary. In Encyclopodia of Social Measurement (pp. 593-599). Amsterdam: Elsevier. https://doi.org/10.1016/B0-12-369398-5/00041-4

Johnston, M. P. (2017). Secondary Data Analysis: A Method of Which the Time Has Come. Qualitative and Quantitative Methods in Libraries, 3, 619-626.

Knapper, C., \& Cropley, A. (2000). Lifelong Learning in Higher Education (3rd ed.). London: Taylor \& Francis Routledge.

Laal, M. (2011). Lifelong Learning: What Does It Mean? Procedia-Social and Behavioral Sciences, 28, 470-474. https://doi.org/10.1016/j.sbspro.2011.11.090

Medel-Añonuevo, C., Ohsako, T., \& Mauch, W. (2001). Revisiting Lifelong Learning for the 21st Century. Paris: UNESCO.

Milana, M. (2012). Political Globalization and the Shift from Adult Education to Lifelong Learning. European Journal for Research on the Education and Learning of Adults, 3, 103-117. https://doi.org/10.3384/rela.2000-7426.rela0070

Morgan-Klein, B., \& Osborne, M. (2007). The Concepts and Practices of Lifelong Learning. London: Routledge. https://doi.org/10.4324/9780203932766

Mundy, K. (1999). Educational Multilateralism in a Changing World Order: UNESCO and the Limits of the Possible. Journal of Educational Development, 52, 27-52.

https://doi.org/10.1016/S0738-0593(98)00054-6

OECD (2007). 2007 Annual Report on Sustainable Development Work in the OECD. Paris: OECD.

Schuetze, H. (2006). International Concepts and Agendas of Lifelong Learning. Compare, 36, 289-306. https://doi.org/10.1080/03057920600872381

Sutherland, P., \& Crowther, J. (2008). Lifelong Learning: Concepts and Contexts. London: Routledge. https://doi.org/10.4324/9780203936207

UIL (2016). Annual Report. Paris: UNESCO.

UIL (2018). Annual Report. Paris: UNESCO.

UIL (2019). Annual Report. Paris: UNESCO.

UNESCO (1998). Higher Education in the Twenty-First Century Vision and Action. Paris: UNESCO.

UNESCO (2000). The Dakar Framework for Action: Education for All: Meeting Our Col- 
lective Commitments. Including Six Regional Frameworks for Action. Paris: UNESCO.

UNESCO (2002). Learning throughout Life: Challenges for the Twenty-First Century. Paris: UNESCO.

UNESCO (2009). 2009 World Education Conference on Higher Education: The New Dynamics of Higher Education and Research for Societal Change and Development. Paris: UNESCO.

UNESCO (2015). Rethinking Education towards a Global Common Good. Paris: UNESCO.

Uvalić-Trumbić, S. (2010). New Dynamics for Higher Education and Research in the 21st Century: What Implications for Small States. In OECS Conference on Higher Education.

Wagner, D. (2011). What Happened to Literacy? Historical and Conceptual Perspectives on Literacy in UNESCO. International Journal of Educational Research, 31, 319-323. https://doi.org/10.1016/j.ijedudev.2010.11.015 